\title{
Erratum to: Perinatal and first year outcomes of spontaneous versus assisted twins: a single center experience
}

Mine Kanat-Pektas • Cigdem Kunt •

Tayfun Gungor • Leyla Mollamahmutoglu

Published online: 14 September 2010

(C) Springer-Verlag 2010

Erratum to: Arch Gynecol Obstet (2008) 278:143-147

DOI 10.1007/s00404-007-0545-8

This article has been retracted due to wrong content with serious consequences.

The online version of the original article can be found under doi:10.1007/s00404-007-0545-8.

M. Kanat-Pektas · C. Kunt · T. Gungor - L. Mollamahmutoglu Department of Perinatology,

Dr Zekai Tahir Burak Women's Health

Education and Research Hospital, Ankara, Turkey

M. Kanat-Pektas $(\bowtie)$

Ertugrul Gazi Mah, Kutlugun Sok. No: 37/14,

06590 Iccebeci, Ankara, Turkey

e-mail: minekanat@hotmail.com 